\title{
ECONOMIC AND ENVIRONMENTAL ANALYSIS OF SHRIMP FARMING IN CHILIKA LAKE, INDIA
}

\author{
Mishra, LOPAMUDRA \\ Sambalpur University, India, Email: mlopa@hotmail.com
}

\begin{abstract}
The shrimp culture industry around Chilika Lake has expanded in the last two decades under the rationale of providing economic benefits at national, regional, community and household levels. Salinisation and pollution of agricultural land especially rice paddies by seepage usually ruin crops and render the land unsuitable for agriculture. As a result there is the decline in the yield rate, which led to the conversion of agricultural land to shrimp ponds. After the shrimp culture for some years the land will be unable to support any natural or agricultural productivity. In due course, these shrimp ponds are abandoned being fit for nothing. The lack of emphasis on enforcement of different legislation, particularly environmental legislation, has allowed the shrimp farms to operate in and around the lake using culture practices that degrade the environment. Thus, the problem with the state is not a lack of legislation, but an unwillingness or inability to enforce it. As a result of this, an established livelihood system is broken down as land with multiple agricultural uses is turned over to mono-crop production. This in turn will lead to abandoned land, which is of no use after few years.
\end{abstract}

KEY WORDS: Chilika lake, shrimp, hedonic pricing, agriculture

\section{INTRODUCTION}

All over the world, local commons are facing more and more complex situations due to changing socio-economic, political, ecological and cultural conditions of their livelihood. Institutions governing the livelihood issues have emerged as crucial agents of sustainability. Institution is defined as a set of rules, eligibility criteria, decision-making arrangements, punishment structures, and action assignments (Ostrom 1990) ${ }^{1}$. In the context of alternative development paradigms, multipleuse common property resources have come under consumptive pressures from local, regional, national and international stakeholders. With the advent of open market economy and globalization, pressure on the common property resources will be more obvious.

Many common properties are under increasing pressure today and are degenerating to open access areas. Although common property has proved to be a stable form of resource management in some traditional societies, the combination of population growth, technological change, climate and political forces has destabilized many existing property institutions (Runge 1986) $)^{2}$. One major reason is population expansion exerting increased competition for resources and producing a growing number of people with group membership claims. Breakdowns in common property management also occur

\footnotetext{
${ }^{1}$ Ostrom, E. (1990), Governing the Commons: The Evolution of Institutions for Collective Action, Cambridge University Press, Cambridge

${ }^{2}$ Runge, Carlisle Ford (1986), "Common Property and Collective Action in Economic Development", World Development, Vol. 14, No. 5, pp. 623-635.

${ }^{3}$ Baland, J.M. and Platteau, J. P. (1996), Halting Degradation of Natural

${ }^{2}$ Runge, Carlisle Ford (1986), "Common Property and Collective Action in Economic Development", World Development, Vol. 14, No. 5, pp. 623-635.
}

when the ownership rights of the community are challenged by outsiders. This may also occur when there is policy intervention in response to market forces and other institutional and technological forces, which undermine the institutions which have managed the resource.

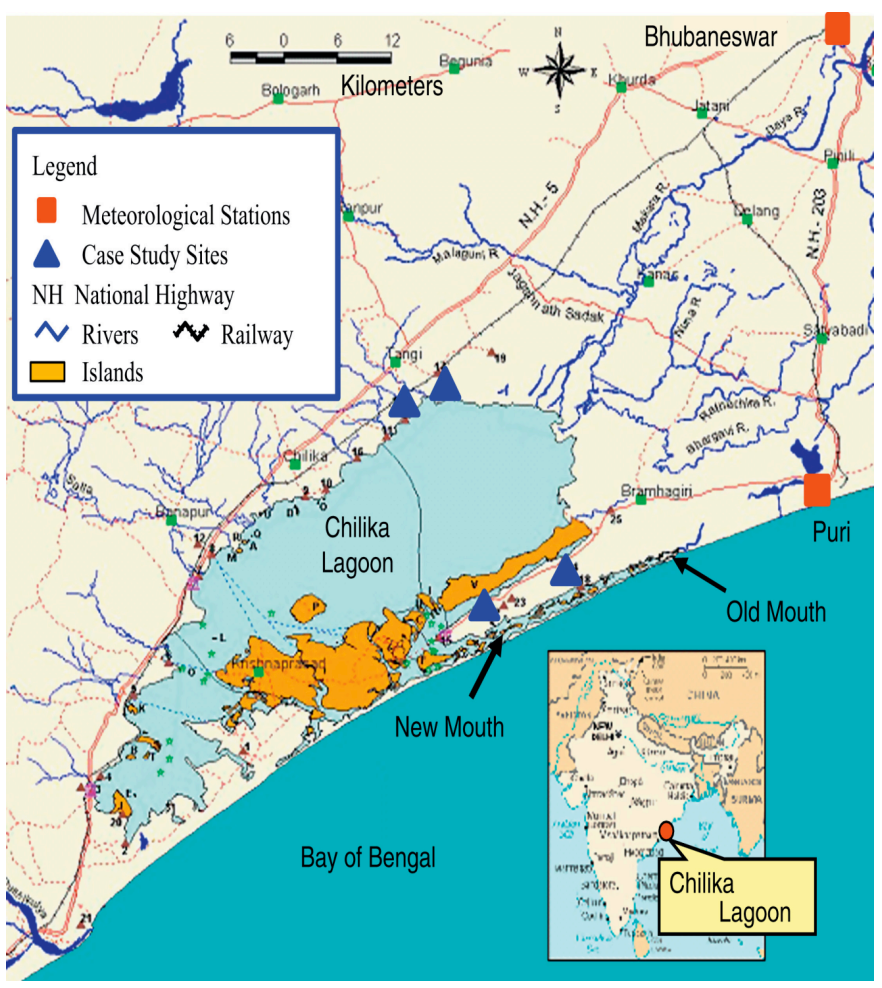

Figure 1. Location map of Chilika Lagoon

At a general level, all common resource users are confronted with the problem of how to reduce or eliminate externalities 5 
related to resource management. If the consumption or production activity of one individual or firm affects another person's utility or firm's production function so that the conditions of a Pareto optimal resource allocation are violated, an externality exists. The human activities in exploiting the natural resources and discharging the materials in the environment are typically such that costs and benefits are not realized in the same scales. In the present study the extraction of resources from Chilika lake and exploitation of the same or release of effluents into the lake or around the lake creates costs for the society. These costs are not normally reflected in the ways the market prices things.

\section{CHILIKA LAGOON}

Chilika lagoon is a coastal ecosystem. The Chilika lagoon, $\left(19 \mathrm{o} 28^{\prime}-190\right.$ 54' $\mathrm{N}$ latitude and 85o 05' -850 38' $\mathrm{E}$ longitude), located in the east coast of the state of Orissa, India, is the largest lagoon in Asia (Fig 1). It is separated from the Bay of Bengal by sandbar whose width varies between $100 \mathrm{~m}$ to $1.5 \mathrm{~km}$; a long outer $32 \mathrm{~km}$ channel connects the main lagoon with the Bay of Bengal near the village Arakhkuda. The pear shaped lagoon is spread over three coastal districts of the state: Puri, Khurda and Ganjam. In the early $20^{\text {th }}$ century, the lagoon area is reported to have varied between $1165 \mathrm{~km}^{2}$ in the monsoon season and $906 \mathrm{~km}^{2}$ in summer. However, land reclamation for agriculture, aquaculture and human settlements, along with sediment inflow from the catchment, had reduced the average lagoon area to $760 \mathrm{~km}^{2}$, based on late1990s satellite images.

Local commons are essential to the livelihoods of many of the world's poorest people. Today the main concern is to integrate sustainable livelihood with conservation of the nature for the attainment of sustainable development. Rules governing the use of common property can be more easily established when the users of the common property have similar interests. At the local level users interact in a structure called social dilemmas. Here the individual gain in exploiting the commons enters into conflict with the general interest. The degradation of the local commons may be due to the failure on the part of the community to co-operate in its protection.

A resource that is to be managed or improved collectively should be accessible to the group members to facilitate control and exclusion of outsiders. It should be small enough for a group to effectively govern. Theories relating to the management of common property resources (Baland and Platteau, $1996^{3}$; Ostrom, $1990^{4}$; Runge, 1986 $6^{5}$ ) outline the conditions for better management of CPR. It has been observed that the greater social cohesion within the group is facilitated by a small number of users, by homogeneity of members in terms of shared values and economic dependence on the resource.

When one looks at the Chilika lake from the perspective of a common property resource, it has been observed that during 1990s, shrimp farming around the lake has questioned the sustainability of the lake ecosystem. Now-a -day people not only depend on the lake for capture fisheries but also for the culture of shrimp in and around the lake. This in turn is affecting the livelihood of the people who depend on the lake and those who depend on agricultural production. The number of stakeholders depending on the lake is changing. There is a

\footnotetext{
${ }^{3}$ Baland, J.M. and Platteau, J. P. (1996), Halting Degradation of Natural Resources: Is there a Role for Rural Communities? Oxford: Clarendon Press and the Food and Agriculture Organization of the United Nations.

${ }^{4}$ Ostrom, Elinor (1990), Op. cit.

${ }^{5}$ Runge, Carlisle Ford (1986), Op.cit.
}

rise in the number of users and a decline in the homogeneity of the users of the lake. For all these there lies the need to study the lake. The present study center on questions like, whether the price of land differs significantly between two time periods i.e. before and after shrimp culture has taken place. Whether policy measures at all has been initiated to stop environmental pollution by the state government? If at all, what type of policy measures they are? Whether people are willing to pay for the treatments of the effluents discharged from the shrimp ponds?

In Chilika Lake there are two types of shrimp farming i.e, pond culture and gheri culture. In the 1970s, after nationalization of scheduled commercial banks, liberal loans were advanced for purchase of trawler to catch fish in the sea. The middle class of people took advantage of this facility and earned a good return by exporting marine product including shrimps. In the later stage, the government of Orissa allotted some patches (measuring 300 acres) for shrimp culture in the shore of Chilika at Sunamuhin in Brahmagiri of Puri district and later on in other blocks under the "Economic Rehabilitation of Rural Poor" ERRP scheme in the banner of poverty eradication programme during $7^{\text {th }}$ Plan to the weaker section. It started in the year 1984-85. Under this scheme, each beneficiary was provided with 0.50 acre excavated shrimp culture tank. The excavated earth was used for construction of mud embankment of the tank. The scheme has enabled the landless poor each to get an average gross income of Rs 7,000 per annum from only 0.2 ha of pond developed by the Government and handed over to the poor. Shrimp culture was found to be highly lucrative and profitable with a short gestation period for investment to yield high return. Thus, people in and around Chilika as well as outsiders were attracted to shrimp culture on large scale ${ }^{6}$.

Liberalisation and the 1991 lease policy gave a boost to both legal and illegal shrimp culture in and around Chilika. For shrimp culture, gheries were made by PFCSs, the fishermen and the non-fishermen. Gheries are made either of earthen embankment or bamboo and net enclosure. When gheries are made by putting up an earthen embankment it is called gheribandha. A gheribandha is made up of low height earthen wall up to three feet height encircling a large area. Gheries are also made by nylon net enclosure by fixing bamboo and wooden poles inside Chilika lake usually near the bank of the lake. Even people have encroached, some portion of deeper Chilika. This is known as pen culture or cage culture or shrimp gheries or chingudi gheries.

In the case of both chingudi gheries and gheribandha, first all the marine species are cleaned and then the stocking is done with wild $P$. monodon seed. The stock grows on natural food available. There is no need of giving any supplementary feed to the shrimp as there is sufficient plankton to support the shrimps in the lagoon. Sometimes, snails are smashed to be given as feed to the shrimp in gheribandha shrimp culture. Harvest is done after the monsoon is over. Water level of Chilika lake changes depending on the movement of moon. There is high tide in every full moon day and low tide in every new moon day in a month. As a result the water level of the net enclosures and earthen embankment also changes. In the full moon day water enters through inlets and the water level increases and after full moon day the water of the lagoon recedes for the next fifteen days. So because of this phenomenon, there lies no need for the exchange of water in both the shrimpi gheries and gheribandha.

\footnotetext{
${ }^{6}$ Samal, K.C. et al (1999), Socio-Economic Survey of Villages in and around Chilika, NKC Center for Development Studies, Bhubaneswar. 
In the "confined pond" shrimp culture around Chilka Lake, small ponds of $0.2-0.5$ ha water spread area with a water depth ranging $0.8-1.2 \mathrm{~m}$. are formed. The individual operated shrimp ponds encircled by earthen embankments are either in Common Property Resource (CPR) area or previously existing paddy fields. The pond bottom is tilled, limed and manured initially. The ponds are filled by the seasonal monsoon rains in July-August and water turns brackish by the leaching of salt from the pond soil. Since evaporative loss of pond water is not compensated, the water level gradually comes down. Water levels in some ponds at the end of the first crop permits stocking the ponds again for the second crop (winter crop), while in others the level is so low that they cannot be stocked again. The second crop harvest is done during February and the ponds become totally dry and remain so until the onset of the monsoon.

Coming over to paddy farmers generally, two types of lands come into picture. First, lands affected by saline water and effluents of shrimp farming. Second, lands those are not at all affected by the shrimp farming. In the first type, i.e. the lands which are near to the shrimp ponds or near to the land where the effluents of the ponds are discharged. With the rainwater generally these effluents pass over to the nearby land and the productivity of the land is affected by rise in salinity of the soil. Because of this there has been a tendency on the part of the agricultural farmers to convert the agricultural lands to shrimp ponds. There has been debate on this conversion of land. Theoretically the debate arises because of the non-fulfillment of weak axiom of sustainability criteria. The concept of sustainability is divided into two sub concepts: 'strong' and 'weak' sustainability. Whereas the notion of 'strong sustainability' leads to a concern over resource environment and the ecological basis of development, the weak sustainability' indicates the possibility of resource substitution between manmade and natural capital for maintaining the resource productivity. Besides this, another traditional practice exists which is shrimp larvae collection from the shoreline during tides / collection of shrimp larvae from the mouth of the lake to the sea.

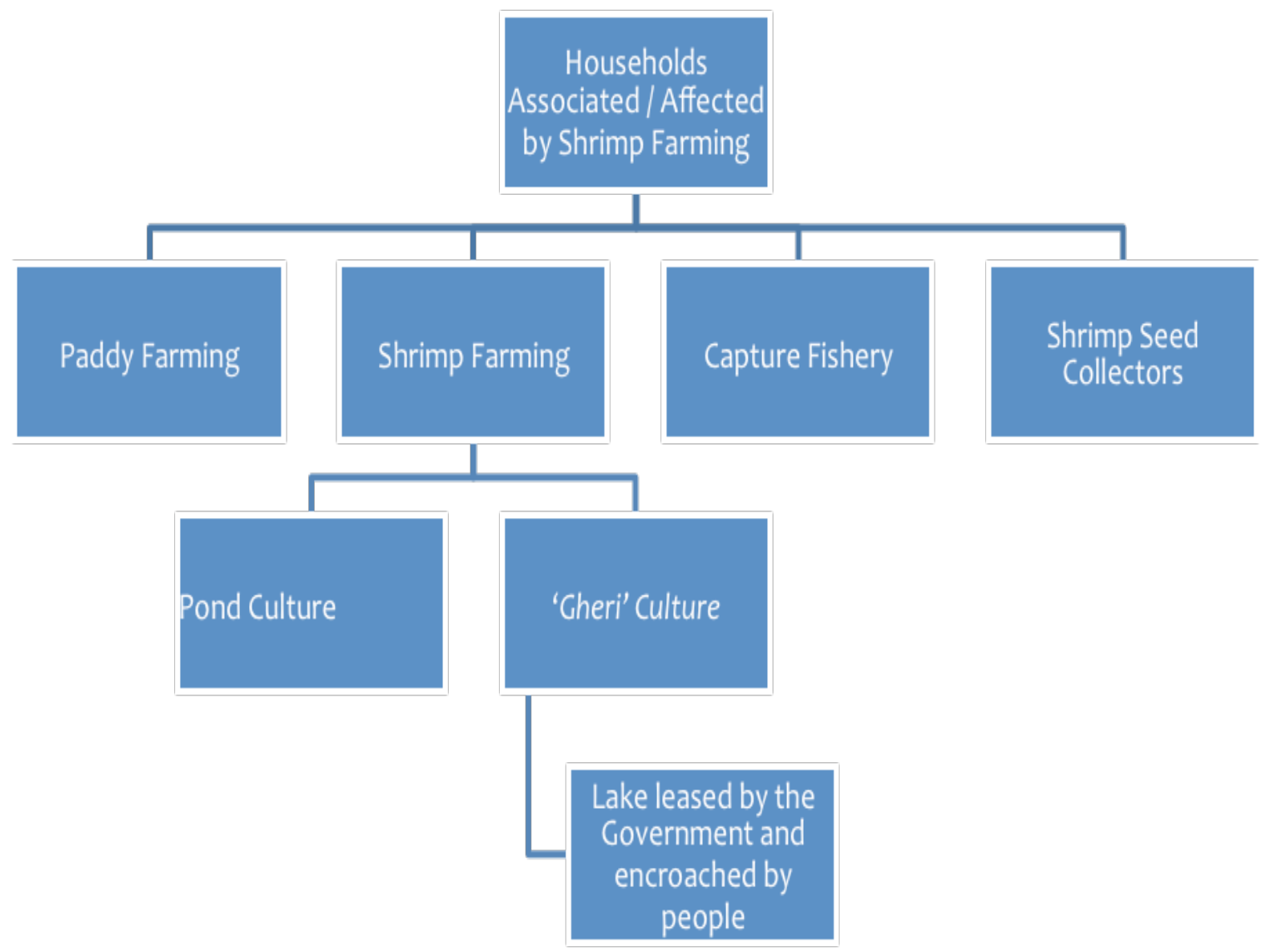

Figure 2. Flow Chart Different Stake Holders Affected by Shrimp Farming in Chilika Lake

\section{SELECTION OF VILLAGES AND SAMPLES COLLECTED}

In the present study as shown in the flow chart 1 , five different stakeholders are considered. They are, i) households associated with shrimp farming which is again divided into two parts i.e. households associated with shrimp culture in ponds and households associated with shrimp gheries (both net \& embankment), ii) households associated with paddy farming, iii) households associated with capture fishery and iv) households associated with shrimp seed collections. These five types of households are directly associated / affected by the shrimp culture in the Chilika Lake.
Data were collected from different stakeholders i.e., paddy farmers, shrimp farmers, households doing shrimp gheri culture and shrimp larvae (seed) collectors. Keeping in view the linkages that exist among the communities depending on the lagoon and its resource management, data from thirty two villages around the lake are collected as in Table 1.

The selection of the villages is made purposefully to include various interrelated aspects like region, castes, sub castes, different occupations etc. Both fishermen and non-fishermen villages are selected. From each village then samples are selected using stratified sampling. 
Figure 3. Flow Chart Different Stake Holders Affected by Shrimp Farming in Chilika Lake

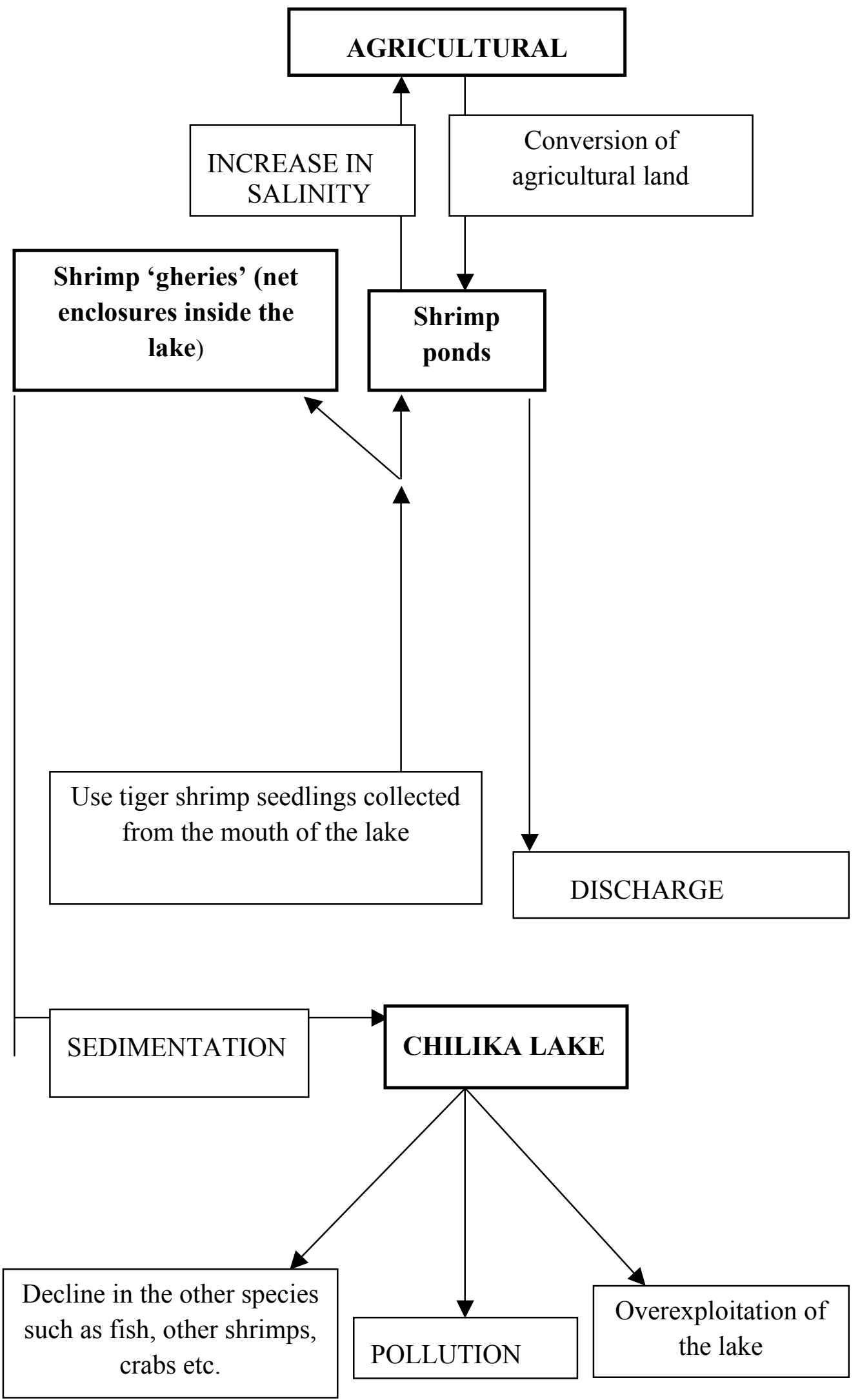


Data for five different stakeholders are collected. They are: i) Household depending on capture fishing from the lake; ii) Household doing paddy cultivation around the lake; iii)
Household doing shrimp culture in pond; iv) Household doing shrimp culture in gheries and v) Household doing shrimp seed collection.

\begin{tabular}{|c|c|c|c|c|c|}
\hline Villages/Hamlet & G.P. & Block & Tehsil & District & Location \\
\hline Analakuda & Nuapada & Krushnaprasad & Krushnaprasad & Puri & East \\
\hline Baghamunda & Satapada & Krushnaprasad & Brahmagiri & Puri & East \\
\hline Bajrakote & Bajrakote & Nuapada & Krushnaprasad & Puri & East \\
\hline Balabhadrapur & Satapada & Krushnaprasad & Brahmagiri & Puri & East \\
\hline Bankijal & Satapada & Krushnaprasad & Brahmagiri & Puri & East \\
\hline Barakudi & Badabenakudi & Brahmagiri & Brahmagiri & Puri & West \\
\hline Bhagabanpur & Manika & Krushnaprasad & Brahmagiri & Puri & East \\
\hline Bhubanapur & Gadarudanga & Brahmagiri & Brahmagiri & Puri & East \\
\hline Chandraput & Nimikheta & Chilika & Banapur & Khurda & West \\
\hline Gabakunda & Arakhkuda & Krushnaprasad & Brahmagiri & Puri & East \\
\hline Gabapadar & Nimikheta & Chilika & Banapur & Khurda & West \\
\hline Janhikuda & Nuapada & Krushnaprasad & Krushnaprasad & Puri & South \\
\hline Karimpur & Badabenakudi & Brahmagiri & Brahmagiri & Puri & East \\
\hline Keutakudi & Arakhkuda & Krushnaprasad & Brahmagiri & Puri & East \\
\hline Kuhudi & Kuhudi & Tangi & Tangi & Khurda & North \\
\hline Kurupal & & Krushnaprasad & Krushnaprasad & Puri & East \\
\hline Nuagaon & Satapada & Krushnaprasad & Brahmagiri & Puri & East \\
\hline Nuapada & Nuapada & Nuapada & Krushnaprasad & Puri & East \\
\hline Panasapada & Panasapada & Krushnaprasad & Brahmagiri & Puri & East \\
\hline Panda & Panasapada & Krushnaprasad & Brahmagiri & Puri & East \\
\hline Rayapur & Manika & Krushnaprasad & Brahmagiri & Puri & East \\
\hline Sanapatana & Arakhkuda & Krushnaprasad & Brahmagiri & Puri & East \\
\hline
\end{tabular}

Table 1. List of the Sample Villages around Chilika Lake

\section{IMPACT OF SHRIMP FARMING ON ENVIRONMENT AND AGRICULTURE}

Shrimp aquaculture affects livelihood by disrupting traditional systems of production, distribution and social relations. Shrimp farming relies on the natural environment for land, water, feed and seedlings, as do capture fisheries and agriculture. The expansion of shrimp aquaculture inevitably generates competition with other users of these same resources, including peasant farmers, fishermen, local elites, local traders, conservationists, urban consumers, the tourism industry and some state agencies. The conversion of agricultural land to shrimp ponds is one of the major problems faced by the people in this area leaving behind the land unsuitable even for agriculture. Big businessmen and the people from the elite class are purchasing the lands from the local people at a very high rate and the small and marginal farmers are selling their own land to these people looking at the short term profits. The empirical model below basically looks into how the difference in land price is influenced by certain important factors.

\subsection{Empirical Model}

Let us first discuss briefly the extent to which the land price differed between two time period i.e. 'before and after' the shrimp culture has taken place in and around Chilika lake. Here it can be noted that the price of the land is significantly different when we consider the before and after situation. It is relevant to look into the land prices of both agricultural land which is mostly used for paddy cultivation and the land used for shrimp ponds. Table 2 indicates that the mean value of the price of agricultural land per acre used for paddy cultivation stood at Rs. 14250 before ten years and has increased to 32937.5 after the shrimp culture in pond has started in this region.
Table 2. The Average Value of the Agricultural Land in and around Chilika Lake

\begin{tabular}{|c|c|c|}
\hline Land Value & Mean & Std Deviation \\
\hline Before ten years & 14250 & 6506.407 \\
\hline Present price & 32937.5 & 14699.06 \\
\hline
\end{tabular}

One thing can be noted here that though the mean value of the price of agricultural land differs between the two time periods, we are not sure whether the difference is 'statistically significant'. To test the statistical significance of the land price, 'paired sample t-test' has been undertaken. Here the paired ttest was performed to determine if the rise in land price was significant. The mean rise in price $(\mathrm{M}=18687.5$, S.D. $=$ 9321.793) was significantly greater than zero, $t=8.019$, two tail $\mathrm{p}=0.0000008$, producing evidence that there has been effective rise in the price of the agricultural land. A $95 \%$ confidence about mean difference is $(13720.27,23654.73)$. So the price rise could have been as low as 13720.27 as high as 23654.73. It is important to note here that though in most cases agricultural production has declined over the years, the price of land, rather than declining has increased over the years. So the adverse impact of shrimp ponds on agricultural land i.e. mainly the rise in the salt loading is not reflected in the land prices. In other words, the negative externalities are offset by the positive impact of some other factors. This will be analysed in the following section.

Table 3. Paired t - test for Prices of Agricultural Land

\begin{tabular}{|c|c|c|c|c|c|c|}
\hline \multirow{2}{*}{ Mean } & \multirow{2}{*}{$\begin{array}{c}\text { Standard } \\
\text { deviation }\end{array}$} & \multirow{2}{*}{$\begin{array}{c}\text { Standard } \\
\text { error }\end{array}$} & \multicolumn{2}{|c|}{$\begin{array}{c}95 \% \text { Confidence } \\
\text { Interval }\end{array}$} & \multirow{2}{*}{$\begin{array}{c}\text { t- } \\
\text { value }\end{array}$} & \multirow{2}{*}{$\begin{array}{c}\text { Two tail- } \\
\mathrm{p}\end{array}$} \\
\cline { 4 - 5 } & & & Lower & Upper & & \\
\hline 18687.5 & 9321.793 & 2330.448 & 13720.27 & 23654.73 & $8.019 *$ & .0000008 \\
\hline
\end{tabular}

*: Indicates significance of the t-statistic at $1 \%$ level. 
Table 4 represents the average value of land used for shrimp ponds in and around Chilika Lake. It indicates that the mean value of the price of land used for shrimp ponds stood at Rs. 15705.88 before ten years and has increased to 42352.94 after the shrimp culture in pond has started in this region. It has been observed from the samples that the land prices of agricultural land are less than the price of land used as shrimp ponds in both the time period.

Table 4. The Average Value of the Land Used for Shrimp Ponds in and around Chilika Lake

\begin{tabular}{|c|c|c|}
\hline Land Value & Mean & Std Deviation \\
\hline Before ten years & 15705.88 & 14860.87 \\
\hline Present price & 42352.94 & 25379.47 \\
\hline
\end{tabular}

Table 5. Paired t - test for Prices of Land Used for Shrimp Ponds

\begin{tabular}{|c|c|c|c|c|c|c|}
\hline \multirow{2}{*}{ Mean } & \multirow{2}{*}{$\begin{array}{c}\text { Standard } \\
\text { deviation }\end{array}$} & \multirow{2}{*}{$\begin{array}{c}\text { Standard } \\
\text { error }\end{array}$} & \multicolumn{2}{|c|}{$\begin{array}{c}95 \% \text { Confidence } \\
\text { Interval }\end{array}$} & \multirow{2}{*}{$\begin{array}{c}\text { t- } \\
\text { value }\end{array}$} & \multirow{2}{*}{$\begin{array}{c}\text { Two } \\
\text { tail-p }\end{array}$} \\
\cline { 4 - 5 } & & & Lower & Upper & & \\
\hline 26647.06 & 17040.18 & 4132.85 & 17885.81 & 35408.31 & 6.448 & .000004 \\
\hline
\end{tabular}

*: Indicates significance of the t-statistic at $1 \%$ level.

To test the statistical significance of the price of land used for shrimp ponds, 'paired sample t-test' has been undertaken (Table 5). The mean rise in price $(\mathrm{M}=26647.06$, S.D. $=$ 17040.18) was significantly greater than zero, $t=6.448$, two tail $\mathrm{p}=0.000004$, producing evidence that there has been effective rise in the price of the land used for shrimp ponds. A $95 \%$ confidence about mean difference is (17885.81, 35408.31). So the price rise could have been as low as 17885.81 and as high as35408.31. It is important to note here that in some cases there has been total loss in shrimp culture in ponds and in some cases decline in the profitability over the years. However this is not reflected in the price of land of shrimp ponds i.e. the land price rather than declining has increased over the years. In other words, here also the negative externalities are offset by the positive impact of some other factors. This will be analysed in the following section.

\subsection{Hedonic Pricing}

The hedonic pricing approach seeks to explain the value of a commodity as a bundle of valuable characteristics. One or more of these characteristics may be environmental. The hedonic pricing method is based on the idea that a private good can be viewed as a bundle of characteristics, each with its own implicit price, some of which may be non-market in nature. The hedonic approach is based on the assumption that the environmental factors are attributes of goods or factors of production that are traded in the markets. The benefits / damages, due to improvements /decrease in the environmental quality could be captured through the market price of the related goods.

In the present analysis it has been observed that the price of the land, rather than declining due to the negative externality of shrimp culture, has increased in between two time periods. This may be due to the presence of other factors. In other words the negative impact of the environment on land price might have been offset by the positive impact of other factors. So to understand the nature and extent of influence of various factors on both the land price of agricultural land as well as on the land used for shrimp ponds, the following two models are employed.

\subsubsection{The model for the agricultural land}

The appropriate model for agricultural land is: $\log \left(\mathrm{P}_{\mathrm{L})}=\alpha+\beta_{1}\right.$ Category $+\beta_{2}$ Potential $+\beta_{3}$ Awareness $+\beta_{4}$ $\log$ (Production) $+\beta_{5}$ Distance from the lake $+\beta_{6}$ Distance from the sea $+\beta_{7}$ Distance from the shrimp pond

Here, $\mathrm{P}_{\mathrm{L}}$ : The difference in the price of agricultural land, $\alpha$ : Constant, Category: Category of farmers (Small - 1; Medium 2; Large - 3), Production: Annual agricultural production from the land, Potential: Whether the land could be potentially developed for shrimp ponds (Yes - 1; No - 0) and Awareness: The agricultural farmer's awareness about the possible damage by shrimp culture operations (Aware - 1; otherwise - 0 )

The logarithmic transformation in price and production has been used to 'normalise' the observations.

Table 6. Influence of Different Factors on the Land Prices of Agricultural Land

\begin{tabular}{|c|c|c|}
\hline Independent variables & Coefficients & t-value \\
\hline Constant & $3.707^{*}$ & 19.45 \\
\hline Category & 0.061 & 0.534 \\
\hline Potential & $0.169^{* * *}$ & 1.771 \\
\hline Awareness & 0.124 & 0.615 \\
\hline Log (production) & $0.398^{* *}$ & 1.965 \\
\hline Distance from the lake & -0.031 & 1.151 \\
\hline Distance from the sea & -0.017 & 0.766 \\
\hline Distance from the pond & $-0.095^{* * *}$ & 1.654 \\
\hline $\mathrm{R}^{2}$ Value & 0.8489 & \\
\hline Adjusted R $\mathrm{R}^{2}$ Value & 0.71667 & \\
\hline
\end{tabular}

*: Indicates significance of the t-statistic at $1 \%$ level, **: Indicates significance of the t-statistic at 5\% level and ***: Indicates significance of the t-statistic at $10 \%$ level.

\subsubsection{The model for the land used for shrimp pond}

The relevant model for land used for shrimp pond is:

$\log \left(P_{L}=\alpha+\beta_{1}\right.$ Category $+\beta_{2}$ Source $+\beta_{3}$ Frequency $+\beta_{4} \log$ (production) $+\beta_{5}$ Distance from the lake $+\beta_{6}$ Distance from the sea $+\beta_{7}$ Distance from the village

Where, $\mathrm{P}_{\mathrm{L}}$ : The difference in the land price, $\alpha$ : Constant, Source: Sources of exchange of water (Tide from sea or lake 1; by pumps -2 ; Others -3 ), Frequency: Frequency of shrimp culture per year, Category: extensive-1, semi-intensive-2, other-3 and Production: The total production of tiger shrimps from the shrimp pond.

Here also the logarithmic transformation in price and production has been used to 'normalise' the observations.

Table 7. Influence of Different Factors on the Prices of Land Used for Shrimp Ponds

\begin{tabular}{|c|c|c|}
\hline Independent variables & Coefficients & t-value \\
\hline Constant & $3.352^{*}$ & 5.243 \\
\hline Category & 0.263 & 1.095 \\
\hline Source & -0.085 & 0.573 \\
\hline Frequency & 0.052 & 0.345 \\
\hline Log(production) & $0.206^{* *}$ & 2.002 \\
\hline Distance from the lake & -0.047 & 1.096 \\
\hline Distance from the sea & $0.028^{* *}$ & 1.692 \\
\hline Distance from the village & 0.1805 & 1.1386 \\
\hline $\mathrm{R}^{2}$ Value & 0.53402 & \\
\hline Adjusted $\mathrm{R}^{2}$ Value & 0.1716 & \\
\hline
\end{tabular}

Here: * indicates Significance at 1 percent level, ** indicates Significance at 5 percent level and $* * *$ indicates Significance at 10 percent level

\subsubsection{Results}

The regression results of the influence of different variables on the land price of agricultural land and price of the land used for shrimp ponds in the hedonic pricing model are presented in the table 6 and table 7 respectively. As mentioned earlier that the land prices of agricultural land are less than the price of land 
used as shrimp ponds. Due to high profitability of the shrimp culture, there has been a tendency to convert agricultural lands to shrimp ponds. In the present study out of the total samples, $41.18 \%$ of the shrimp ponds were previously doing the same activity whereas $58.82 \%$ have started it within the last two years prior to the survey. Out of this $80 \%$ have converted their agricultural lands to shrimp ponds and the rest $20 \%$ have converted unproductive lands to the same.

In the table 6 , as expected the variable potential i.e. whether the land could be potentially developed for shrimp ponds, positively and significantly influences the difference in the land prices in the study area. Thus the result suggests that if the agricultural land could be developed to the shrimp ponds then the price of land is higher. Another variable i.e. the distance from the shrimp pond is negatively and significantly related to the differences in the land prices. Thus the greater the distance from the shrimp ponds, the lesser is the price of the agricultural land. However, it is an well known fact that the agricultural production declines, the nearer it is to the shrimp ponds as the salt loading of these lands increases due to seepage. However, the negative and significant relationship between price differential of the agricultural land over the years and the distance from the shrimp ponds indicates that the tendency for the conversion of agricultural land to shrimp ponds is able to raise the price of the agricultural lands nearer to the shrimp ponds than which are far away from the shrimp ponds.

Another important variable which is influencing the land price is the production from the land under consideration. The sign and the magnitude of the variable production indicate that it influences the price of the land positively and significantly. However, the other factors i.e. category, distance from the sea and distance from the lake do not significantly affect the differences in the land prices. However, the last two are negatively related to the differences in the land prices. That means as the distance from the lake or sea increases, the price differences of the agricultural land decreases though not significantly. This also indicates the tendency of conversion of agricultural land to shrimp ponds as these shrimp ponds require saline water for the culture of tiger shrimps for which they depend on the Chilika lake or the sea which one is nearer to them.

To know the influence of farmers' knowledge about the negative externalities that shrimp culture has, the variable awareness has been incorporated in the analysis. This variable influences the land price positively but insignificantly. About $94 \%$ of the sample farmers reported that the rise in salinity of the agricultural land nearer to the shrimp ponds is a major problem in those areas. So they are aware of the negative impact of shrimp farming but they are unable to establish a link between the damage and the land price.

As presented in the table 7 the land price difference of shrimp ponds is influenced significantly by the production of tiger shrimps from those ponds. However the frequency of shrimp culture, though positively related to land prices, is not significant. About $58.82 \%$ of the sample pond shrimp culturists do culture once in a year and the rest $41.18 \%$ do the same twice in a year. The distance from the lake is negatively and insignificantly related to the price of the land used for shrimp culture.

\subsection{Willingness to pay for the Treatment of the Effluents Discharged from the Shrimp Pond}

Since shrimp farming in ponds has a high market value compared to rice, hence people are biased towards the promotion of shrimp culture. However, this bias is the result of an overestimation of the total economic value of shrimp farming. It ignores the long-run social and environmental cost associated with shrimp farming. A cost to the society, by leaving behind a land unsuitable for agriculture or even for shrimp farming is incurred. In the present analysis it has been observed that almost $88.23 \%$ of the sample respondents who were engaged in tiger shrimp culture in ponds were putting the effluents on the bank of the ponds after cleaning the pond. Of the rest either they do not clean the ponds after each harvest or they do not wish to respond the questions relating to the effluents. Those who were putting the sediments on the bank of the ponds were asked if suppose the government or any other agency would undertake an effluent treatment programme and in that programme it would treat the effluents discharged from the ponds, then for this treatment how much they would be willing to pay per crop per square kilometer. It should be noted that the WTP value for the treatment of effluents emanating from the shrimp ponds is influenced by certain factors. They are the total area of the shrimp ponds i.e. size of the farm, total cost of production, income from the shrimp culture, volume of the effluents and the finance i.e. whether the finance is coming from own sources or it is a borrowed one. The components of the total cost of production are costs on labour (permanent), labour (seasonal), fertilizers, feed, seedlings, cleaning, harvesting, medicines, pond repairing, land rent (if any), oil \& electricity, and overhead costs (phone, tax).

The variables distance from the lake and distance from the sea are also taken in the analysis. Usually, most of the farmers remove effluents from the pond bottoms after each harvest and they typically dump them on the bank of the pond or in the nearby land. During rainy season when Chilika expands and submerges landmass, the effluents discharged from shrimp ponds mix with lake water. The effluents discharged from shrimp ponds on the higher side of the lake also flow into the lake. These pollutants stagnate due to typical tidal activity in the lagoon. The increasing influx of rich organic silt and sedimentation to the lake over the years from the shrimp culture ponds around the lake has become an issue, especially since the mid 1980s. However, this is overlooked by the people who are engaged in the shrimp culture and they are least bothered about the effluents discharged from the shrimp ponds. To see whether the distance from the sea or distance from the lake is affecting the willingness to pay, these two variables are incorporated into the analysis.

To know the influence of each variable on the willingness to pay (WTP) value, the following log-linear regression model is used.

$\log (\mathrm{WTP})=\alpha+\beta_{1}$ Size $+\beta_{2} \log ($ total cost $)+\beta_{3} \log ($ income $)+$ $\beta_{4}$ volume eff. $+\beta_{5}$ Borrowed $+\beta_{6}$ Distance from the lake $+\beta_{7}$ Distance from the sea

Where, $\log$ (WTP): Logarithmic value of the willingness to pay,

\section{$\alpha$ : Constant, Size : Size of the farm}

Total cost: Total cost of production for each crop

Income: Income from shrimp ponds

Volume eff.: Volume of effluents released per harvest

Borrowed : Whether the finance is coming from own sources or is borrowed (Borrowed $=1$, Owned $=0$ ) 
Table 8. Factors Affecting the WTP for Treating the Effluents Discharged from the Shrimp Ponds

\begin{tabular}{|c|c|c|}
\hline Independent variables & Coefficient & t-Value \\
\hline Constant & -5.853 & 1.222 \\
\hline Size & 0.634 & 1.522 \\
\hline Total cost & $3.232^{* *}$ & 2.177 \\
\hline Income & $-1.369^{*}$ & 3.936 \\
\hline Volume eff. & $-0.011^{*}$ & 3.53 \\
\hline Borrowed & $-1.01^{* * *}$ & 1.64 \\
\hline Distance from the lake & -0.031 & 0.203 \\
\hline Distance from the sea & $0.169^{*}$ & 3.17 \\
\hline $\mathrm{R}^{2}$ Value & 0.7485 & \\
\hline Adjusted R ${ }^{2}$ Value & 0.553 & \\
\hline
\end{tabular}

Here: * indicates Significance at 1 percent level, ** indicates Significance at 5 percent level and $* * *$ indicates Significance at 10 percent level.

From the table it is evident that the variable size positively influences the WTP but insignificantly. The variable total cost of production is positively and significantly related to the willingness to pay for the effluents treatment. From the above relation it has been observed that the larger farms having higher variable costs have the higher willingness to pay. Another important variable which influences the WTP value significantly is the annual income. The sign and the magnitude of this variable suggest that the shrimp culturists who derive more amount of annual income from the shrimp ponds are not willing to pay more for treating the effluents. The volume of effluent represented by the variable Volume eff, negatively influences the WTP significantly. Another factor which is an important determinant of WTP value is whether the capital employed is borrowed or owned. The sign of the variable suggests that if the capital is borrowed then the level of willingness to pay value is lesser significantly and if it comes from their sources then the WTP value is higher.

\section{IMPLICATIONS OF LAND CONVERSION:}

Shrimp culture ensures high return on investment, however, rapid expansion and intensification of shrimp farming has caused increased concern regarding potential environmental impacts. The fast return on the investment is often due to lack of appropriate institutions (norms and rules) to internalise the cost of extraction. The result is that the long term benefits are traded for short term benefits that often carry with them long term degradation of environmental and social conditions.

The behaviour of shrimp cultivators in ponds and agricultural farmers can be analysed from their strategic behaviour. The agricultural farmers have two strategies i.e., the cultivation of rice or conversion of agricultural land to shrimp ponds. The shrimp culturists have the two strategies i.e., to do moderate shrimp culture or to follow intense culture. Each of them knows what the pay off of each strategy will be. So the game is:

Table 9. Game in Terms of Profitability from the Land Agricultural Farmers

\begin{tabular}{|c|c|c|}
\hline $\begin{array}{c}\text { Pond Shrimp } \\
\text { Culturist }\end{array}$ & Cultivation of rice & $\begin{array}{c}\text { Conversion of agricultural } \\
\text { land to shrimp ponds }\end{array}$ \\
\hline $\begin{array}{c}\text { Moderate Shrimp } \\
\text { Culture }\end{array}$ & $(3,3)$ & $(3,10)$ \\
\hline $\begin{array}{c}\text { Intense Shrimp } \\
\text { Culture }\end{array}$ & $(10,2)$ & $(10,10)$ \\
\hline
\end{tabular}

The above payoffs of the game represent the short term behaviour of both the players. Initially when the agricultural farmer is cultivating rice and the shrimp culturist follows a moderate policy, the payoff is $(3,3)$. When shrimp culturist is shifting from moderate to intense culture, his pay off is rising to 10 in terms of profitability, but that of the agricultural farmers is declining to 2 from 3. This is due to fact that the productivity of agricultural land nearby to the shrimp ponds will decline due to seepage of saline water from these ponds. Now-a-days the agricultural farmers nearer to the shrimp ponds are gradually converting their agricultural lands to shrimp ponds to earn more profits.

The conversion of rice paddies to shrimp ponds is being viewed as an example of the restructuring and intensification of agriculture, as farmers switch to higher value crops. Unfortunately the underlying conditions of low income for rice farming households, indebtedness, limited off-farm employment opportunities and the high profit potential associated with shrimp farming, intensify the pressure to choose short-term exploitation of the resource over the long term benefits. So the pay off of both the players becomes (3, $10)$ if the pond culturists is adopting moderate shrimp culture and agricultural farmer is shifting to shrimp culture. Similarly, if shrimp culturist is following intense culture and the agricultural farmer are converting the land to shrimp ponds, the pay offs become $(10,10)$ in terms of profitability. However this pay off structure is not sustainable if we analyse the situation for a long period as after about twenty or twenty five years the shrimp ponds will be fit for nothing and that will be abandoned. The process of abandonment of shrimp ponds has already been started in the villages around the lake.

It is a well known fact that sustainable development is critically linked with land degradation especially in agrarian economy. When a long term perspective is taken and the same situation is viewed from the point of view of the land quality, the game becomes just the reverse. Just like the previous game, here also the agricultural farmers have the two strategies, i.e., the conversion of agricultural land to shrimp ponds and the shrimp culturist adopts either moderate shrimp culture or intense shrimp culture.

Table 10. Game in Terms of the Soil Quality of the Land Agricultural Farmers

\begin{tabular}{|c|c|c|}
\hline Pond Shrimp Culturist & Cultivation of rice & $\begin{array}{c}\text { Conversion of } \\
\text { agricultural land } \\
\text { to shrimp ponds }\end{array}$ \\
\hline Moderate Shrimp Culture & $(12,12)$ & $(12,5)$ \\
\hline Intense Shrimp Culture & $(5,10)$ & $(3,3)$ \\
\hline
\end{tabular}

When the agricultural farmer is cultivating rice and the shrimp culturist is doing moderate shrimp culture, let the payoff be $(12,12)$. Taking into consideration the profitability of the shrimp business, the agriculturist is converting his land into shrimp ponds. However after a long period, say, 10 years to 15 years, gradually the soil quality of the land will decline and salt loading of that particular land will increase. As a result the pay off in terms of quality of the soil will decline to 5 from 12 . So when the agricultural farmer is converting his land to shrimp pond and the shrimp culturist is going for moderate shrimp culture, their pay off is $(12,5)$.

In a similar manner, let us suppose the moderate shrimp culturist shifts from moderate to intense culture. Similar is the situation for him i.e. in the long run, the shrimp pond might be unsuitable for even shrimp culture. It is a well known fact that shrimp is not an efficient converter of feed (Macintosh and Philips, 1992) ${ }^{7}$ and therefore in commercial shrimp farms as much as $77.5 \%$ of Nitrogen and $86 \%$ of phosphorus is wasted. This either accumulates within the pond or discharged in the environment. Thus, over time land put to shrimp farming could become unproductive for crops. So the shrimp culturist's pay

\footnotetext{
${ }^{7}$ Macintosh DJ, Phillips MJ. (1992), Environmental Considerations in Shrimp Farming, INFOFISH International, Vol. 6, pp 38-42.
} 
off will decline to 5 from 12 . As far as agricultural farmers are concerned, the soil quality of their land will decline due to the negative externality of the intense shrimp culture. This is due to the fact that a large portion of nutrients in shrimp feed becomes waste which is directly discharged into the neighboring land making them unfit for cultivation. So in this above game, the pay off of agricultural farmers will decline to 10 from 12. If the agricultural farmers will shift to shrimp culture and shrimp culturist will follow the intense culture of shrimp, the pay off becomes $(3,3)$ where the sustainability of the land is questionable.

In this process of land conversion from rice to shrimp usually, small landowners have been willing to sell their land and reinvest in other productive activities, though this change of livelihood can also lead to social dislocation and reduced livelihood support. So there is the transfer of land from the former small-scale farmers to larger private shrimp culturists. The means of transfer may be legal sale of deed, forced sale through harassment or sale following degradation of the land by pollution from the shrimp ponds. Again, shrimp culture in the State has increased the land price. As a result the landowners have started selling their lands, which are previously leased out to small farmers. Thus, these farmers now have less land to lease in.

\section{SOLUTIONS FROM GAME THEORY}

Chilika provided livelihood to about one and half lakh people (both fishermen and non-fishermen) living in and around Chilika in about 132 villages. The 1991 lease policy of the state has conferred powers on the District Collector to lease out culture sources. Under the present lease policy, lease is given for three years only. The lease is given to different Primary Fishermen Co-operative Societies (PFCSs) and to other nonfishermen living around the lake. Many of the PFCSs had reportedly sublet their fishery sources. This is due to the fact that shrimp culture requires huge investment on fixed and working capital. Most of the fishermen and PFCSs did not have resources to invest. So the PFCSs depend on outside financiers. The same is applicable in cases of culture sources leased to the non-fishermen villages. When PFCSs or non- fishermen groups could not repay the principal and exorbitant rate of interest, they were trapped to sublease their culture sources. Again as the lease is only for three years, the financiers will try to overexploit the lake as there is no guarantee that after three years they will again get the chance to do so. Here it is important to note that these shrimp 'gheries' are around 22 thousand acres in the leased area and 20 thousand acres of encroached area of the lake.

The problem between the non-fishermen (mainly the financiers) and the fishermen can be understood from their strategic behaviour. The fundamental externality of common property fisheries derives from the resource itself. The resource stock is a factor in each firm's production function. Thus by their harvesting activity the firms impose a production diseconomy on each other. The result is a tendency towards excessive fishing effort and overexploitation of the resource. In the Chilika Lake there is one renewable resource for the fishermen and the non-fishermen i.e. the shrimp stock. Both of them are the exploiters in competition having two possible strategies i.e. either to exploit moderately or intense exploitation. Each of them knows what the pay off of each strategy will be, depending on what policy the other follows. So the game is:
Table 11. Game in Terms of Exploitation of the Lake Non-fishermen

\begin{tabular}{|c|c|c|}
\hline Fishermen & Moderate exploitation & Intense exploitation \\
\hline Moderate exploitation & $(8,8)$ & $(3,10)$ \\
\hline Intense exploitation & $(10,3)$ & $(4,4)$ \\
\hline
\end{tabular}

The pairs of numbers in the parentheses indicate the payoffs for each combination of actions, with the fishermen's payoffs given first in each case.

As mentioned before, changes in the fishery leasing policy, especially since the early $1990 \mathrm{~s}$, have resulted in the encroachment on the fishing rights of traditional fishermen. The changing composition of labour force and the people involved in the tiger shrimp business reflect the influx of outsiders i.e. many businessmen middlemen and some bureaucrats have entered into the lake area. This has led to social tension and disharmony.

Now if the fishermen decide to undertake intense exploitation of the lake, but non-fishermen decide to moderately exploit it, then the fishermen get a higher payoff of 10 and the nonfishermen get a very low payoff of 3 . From the above it is clear that the best outcome or most efficient solution from social point of view is \{moderate exploitation, moderate exploitation $\}$. But the question is how likely it will occur? Let us consider the fishermen's choices. If the non-fishermen choose moderate exploitation, the best option for the fishermen is intense exploitation as 10 are greater than 8. If the nonfishermen choose the intense exploitation, fishermen best option is again intense exploitation, since the payoff 4 is greater than 3 . So no matter what the non-fishermen do, the fishermen will go for intense exploitation of the lake. In a similar way, for the non-fishermen also, the strategy of intense exploitation strictly dominates the strategy for moderate exploitation. So the outcome is intense exploitation, intense exploitation $\}$, which is socially inefficient.

This has led to social tension and disharmony and many times there are conflict between the local fishermen and local nonfishermen group who are threatened by the outsider big businessmen in their traditional fishing zone. So, how to overcome this problem? Let the incomes of the non-fishermen and fishermen are presently 15 units. However, to maintain the level of their present catches, they need to protect the lake from the encroachments of big businessmen and bureaucrats of the state. For that there should be state intervention. However, the role of the state regarding this is highly influenced by the big business men. The insensitive and inadequacies of the governance agencies to protect the marginalized groups provide the context for collective action.

Table 12. Game in terms of Lobby Non-fishermen

\begin{tabular}{|c|c|c|}
\cline { 2 - 3 } \multicolumn{1}{c|}{ Fishermen } & A & B \\
\hline A & $(12,12)$ & $(9,15)$ \\
\hline B & $(15,9)$ & $(3,3)$ \\
\hline
\end{tabular}

So let us assume that to succeed in securing that protection from the state government, the local fishermen and nonfishermen should make lobbying efforts and the total cost of which will amount to 5 units. If both the groups defect i.e. if both the groups refuse to exercise pressure on the government until it agrees to act in their interests, the competition from the big businessmen of the state will bring their individual incomes down to a mere 3 units $(3,3)$. The total benefit of the lobbying action i.e. the joint pay off $(\mathrm{A}, \mathrm{A})$ minus the joint pay off $(\mathrm{B}$, B) is $24-6=18$, which is much larger than the total cost 6 . If both the fisherman and the non-fisherman cooperate in the sense that both of them agree to share the cost equally 
between $(\mathrm{A}, \mathrm{A})$, then will both be assumed of receiving a payoff of 12 units. Moreover, the lobbying action is so rewarding that it can pay a single player to bear the entire cost of it $(A, B)$ or $(B, A)$. The politically active player will then get 9 units while the passive player (the free rider) will of course get more i.e. 15 units in this case.

Thus, in the present situation both the groups should try to influence the state government collectively to formulate some policy to protect the lake from the outsiders. The fishermen and non-fishermen should be expected to make effort to bring back the state to perform the role which it came into existence.

\section{CHILIKA AND LIVELIHOOD}

The communities depending on Chilika for their livelihood are not homogeneous entities but consist of diverse groups differentiated by caste, class, religion and within and between each of these groups by gender and age.
However, efficient governance requires a common preference for the resource and mutual trust among resource users (Ostrom, 1990) Op. cit. The governance of the lake is situated within the framework of three levels of governance such as i) operational governance, ii) collective-choice governance iii) constitutional - choice governance. Operational governance involves decisions about how to appropriate and manage resources, provide information, monitor actions, and enforce rules. Collective choice governance pertains to rules that shape how participants make decisions about operational-level governance. Constitutional-choice governance refers to the assignment of rights and duties of decision participants and designation of rules affecting the interaction among those participants. Hence, constitutional-choice decisions affect and constrain collective-choice; in turn, collective-choice rules affect and constrain operational governance.

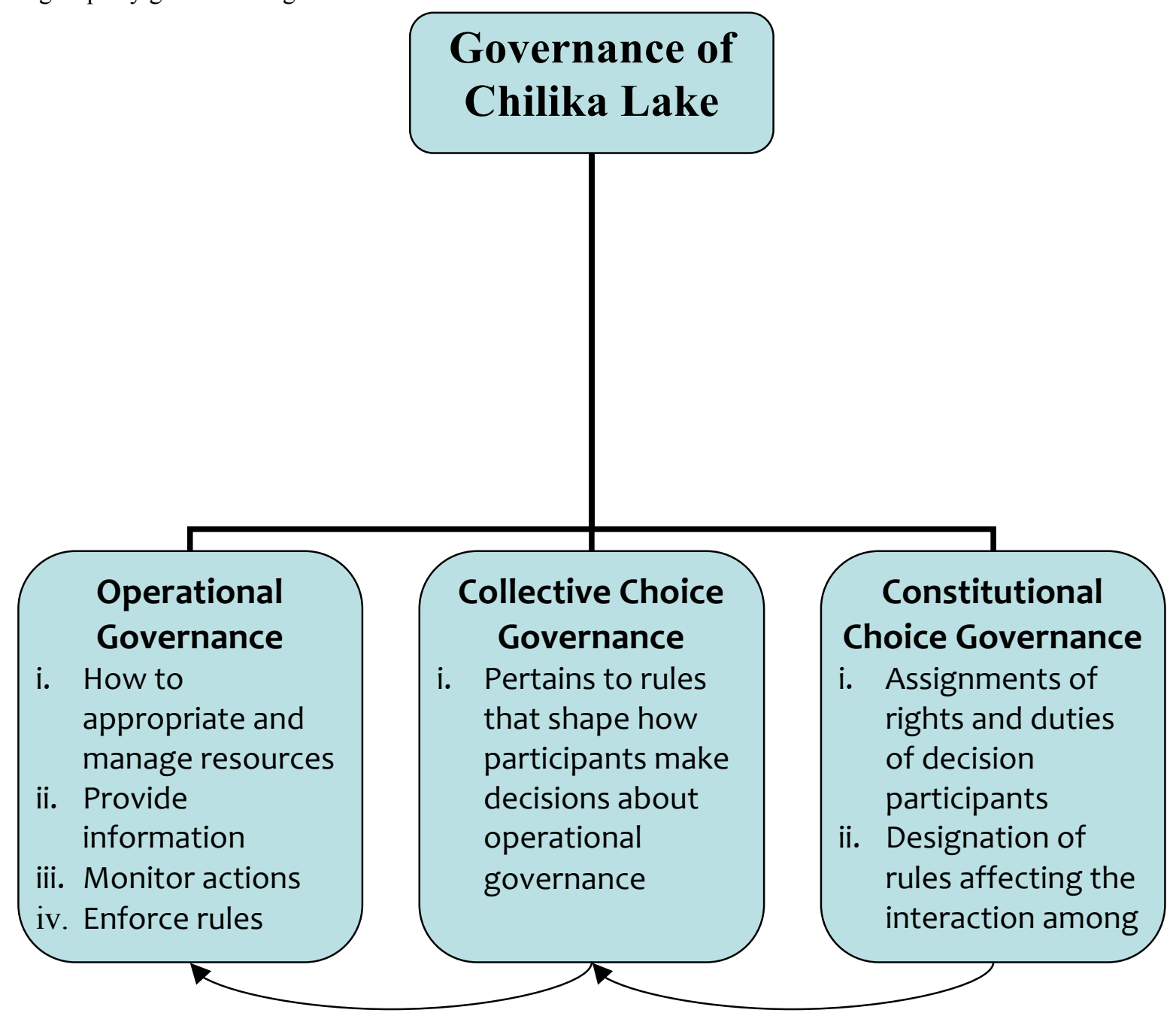

Figure 1. Governance of Chilika Lake

The fishermen who depend on the lake for their livelihood may confront with two types of decisions. They are:

i) Heterogeneous user group with respect to the management of the lake,

ii) The degree of direct dependence on the Chilika lake.

i) Heterogeneous user group with respect to the
management of the lake:

People think themselves both as separate entities and as member of a social community. In the traditional society people think themselves first as members of the community and only afterwards as independent individuals. An inherent spirit of co-operation is present among them even with large economic differences and social stratification. However this spirit is muted in modern industrial societies, where people are first and foremost "individuals".

Thus,

a) At the first level, there is heterogeneity of individual interests with respect to how the lake is managed as individuals differ with respect to income levels and social and cultural traditions or norms.

b) Due to the first or basic heterogeneity, the members of the user group may have diverse preferences for the products which they get from the lake. So they prefer different 
product mix. This could be the second level of heterogeneity.

c) Diverse product preferences will result in different preferences for resource management regimes, which can be labeled as third degree of heterogeneity. This third degree of heterogeneity has led to the conflict between the fishermen and the non-fishermen communities.

Figure 2. User Group Heterogeneity in Lake Management

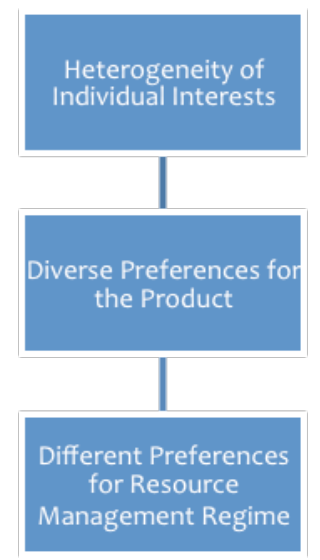

\section{ii) The degree of direct dependence on the lake:}

The traditional fishermen depend on the lake located close to their habitats for their money income which they can get from selling the fish products from the lake. These groups have a one to one direct dependence on the lake as these things are necessary for their subsistence. The degree of direct dependence will depend on the share of direct returns from the lake in the total utility bundle. In the case of the utility bundle being comprised of returns from the lake only, the degree of dependence will be very high as there is no possibility of substitution. This is the case for the traditional fishing communities who depend on the lake for their subsistence livelihood.

The introduction of new shrimp farming technology has proceeded with no concern about local knowledge, practices, preferences and resource use. The control of local resources has shifted from communities to local institutions as well as to institutions located outside. This has affected the livelihood of the traditional fishing community and led to social disruption.

\section{CONCLUSIONS}

Rivalry in consumption and difficulty of exclusion make provision and sustenance of common pool goods particularly challenging. The inability on the part of the government to regulate access to the Chilika lake and the resistance of some of the fishermen communities towards the exclusionary policies i.e. not to allow the non-fishermen as well as some fishermen to do shrimp gheries inside the lake have forced the state government to intervene.

In practice every society has its own means and adaptations to deal with the natural environment common pool resources and its own local level systems of resource management, which are based on the knowledge and experience of the resource users themselves. Institutional, environmental and policy contexts differ to some extent in each locality and each country. It is not feasible to prescribe policies or institutional reforms to be applied in a mechanical fashion. A general rule is that governments should be made representative and accountable, basic human rights protected and property rights should be equitable, clear and secure. When one looks at the solutions to the environmental problems which the local people around the
Chilika lake face, it seems reasonable that the traditional fishermen who are the customary users of the Chilika lake should be compensated for their losses. The interests of others who are negatively affected by externalities arising from shrimp farming (including future generations) should be taken fully into account.

However, given the many limitations of compensation schemes it would be more practical and feasible and correct to prevent the households from polluting the lake in the first place through regulatory means and economic incentives. Regulatory solutions are however not so responsive. As they are imposed by decision makers in the government, and usually by higher levels of government, they tend to be relatively unresponsive to changes in technology and economic conditions of the people living around the commons. Again they do not have the actual information regarding a particular aspect as they many times get information from the different interests groups who are busy to gain their own self interests. The government of Orissa's policy regarding this lake is of regulatory type. Keeping that in view it can be recommended that the regulations regarding the lake should be reviewed from time to time.

\section{REFERENCES}

1. Agrawal, A.(2001): "Common Property Institutions and Sustainable Governance of Resources", World Development, 29 (10): 1649-1672.

2. Baland, J.M., J. P. Platteau (1996): Halting Degradation of Natural Resources: Is there a Role for Rural Communities? (Oxford: Clarendon Press and the Food and Agriculture Organization of the United Nations).

3. Baland, J.M., J. P. Platteau (1997): "Coordination Problems in Local Level Resource Management", Journal of Development Economics, 53: 197-210.

4. Baland, J.M., J. P. Platteau (1999): "The Ambiguous Impact of Inequality on Local Resource Management", World Development, 27(5): 773-788.

5. Baumol, W., W. Oates (1988): The Theory of Environmental Policy (Cambridge: Cambridge University Press).

6. Berkes, F. (1985): "Fishermen and the Tragedy of the Commons", Environmental Conservation 12: 199-206.

7. Bromley, D. (1991): Environment and Economy: Property Rights and Public Policy (Blackwell, Oxford).

8. Chopra, K., G. Kadekodi, M. Murthy (1989): "People's Participation and Common Property Resources", Economic and Political Weekly, 24: A189-A195.

9. Coase, R. (1960): "The Problem of Social Cost", Journal of Law and Economics, 3(1): 1-44.

10. Costanza, R., H.E. Daly (1992): "Natural Capital and Sustainable Development", Conservation Biology, 6: 3746.

11. Das, G.S. (1993):" The Report of the Fact-Finding Committee on Chilika Fisheries", Submitted to Orissa High Court on 16. 8. 93.

12. Dasgupta, P., K.G. Maler (1993): "Poverty and the Environmental Resource Base", Mimeo, University of Cambridge.

13. Demsetz, H. (1964): "The Exchange and Enforcement of Property Rights", Journal of Law and Economics, 70(4): 414-430

14. Demsetz, H. (1967): "Towards a Theory of Property Rights", American Economic Review, 52(2): 347-379.

15. Hardin, G. (1968): "The Tragedy of the Commons", Science, 162. 
16. Macintosh D. J., M. J. Phillips (1992): "Environmental Considerations in Shrimp Farming", INFOFISH International, 6: 38-42.

17. Maler, K.G., A. Xepapadeas, A. Zeeuw (2000): "The Economics of Shallow Lakes", Discussion Paper 131. The Beijer Institute. Stockholm.

18. Mishra, L. (2003): "Tiger Shrimp Culture in Chilika Lake in Orissa, India", presented in the School and Conference on Theoretical Topics in Ecological Economics, The Abdus Salam ICTP, Italy, February.

19. Murray, J.D. (1989): Mathematical Biology (Berlin: Springer Verlag).

20. Olson, M. (1965): The Logic of Collective Action (Cambridge: Harvard University Press).

21. Ostrom, Elinor (1990): Governing the Commons: The Evolution of Institutions for Collective Action (Cambridge: Cambridge University Press).
22. Runge, Carlisle Ford (1986): "Common Property and Collective Action in Economic Development", World Development, 14(5): 623-635.

23. Samal, K.C. et al (1999): "Socio-Economic Survey of Villages in and around Chilika", NCDS, Bhubaneswar, India.

24. Starrett, David A. (2003): "Property Rights, Public Goods and the Environment" in Maler K.G. and J. R. Vincent (ed) Handbook of Environmental Economics, 1(Elsevier Science).

25. Wade, R. (1987): “The Management of Common Property Resources: Collective Action as an Alternative to Privatisation or State Regulation", Cambridge Journal of Economics, 11: 95-106. 